ISSN. 2621-9832

JURNAL MathEdu (Mathematic Education Journal) http://journal.ipts.ac.id/index.php/MathEdu

Vol. 4. No. 3 November 2021

\title{
PENGARUH PEMBELAJARAN MATEMATIKA DENGAN MENGGUNAKAN MODEL RECIPROCAL TEACHING TERHADAP KEMAMPUAN BERPIKIR KREATIF MATEMATIKA SISWA MTsS UTAMA NAGASARIBU
}

\author{
Oleh: \\ Sahriani Siregar', Mohd. Arifin², Alvi Sahrin Nasution ${ }^{3}$ \\ ${ }^{1,2,3}$ Fakultas Keguruan dan Ilmu Pendidikan Universitas Graha Nusantara
}

\begin{abstract}
Abstrak
Penelitian ini merupakan penelitian eksperimen semu dengan memperoleh informasi yang relevan untuk permasalahan yang diteliti dan menungkan analisis yang obyektif untuk memperoleh kesimpulan yang valid. Untuk alat mengambil data digunakan test dan observasi. Dari hasil pre-tes diperoleh 34 orang siswa belum berhasil memahami materi himpunan. Sementara 6 orang siswa sudah berhasil memahami materi himpunan. Dilihat dari rata-rata kemampuan awal siswa sebelum materi himpunan diajarkan sebesar 47,38. Maka tingkat penguasaan siswa pada materi himpunan dengan pembelajaran konvensional sangat rendah. Setelah melakukan pembelajaran dengan pembelajaran Reciprocal Teaching diperoleh 2 orang siswa belum berhasil memahami pokok bahasan volume kubus dan balok. Sementara 38 orang siswa sudah berhasil memahami materi himpunan. Dilihat dari rata-rata kemampuan awal siswa sebelum penerapan Model pembelajaran Reciprocal Teaching pada materi himpunan yaitu sebesar 47,38 dan setelah melakukan perbaikan hasil pembelajaran diperoleh data sebesar 80,13, maka perbandingan tingkat penguasaan siswa pada materi himpunan dapat ditingkatkan yaitu dengan kategori adalah baik. Berdasarkan hasil penelitian, maka dapat disimpulkan bahwa terdapat peningkatan kemampuan berpikir kreatif siswa yang diajarkan setelah menerapkan pembelajaran Model pembelajaran Reciprocal Teaching pada materi himpunan di kelas VII MTsS Utama Nagasaribu Tahun Pelajaran 2020-2021
\end{abstract}

Kata kunci : kemampuan berpikir kreatif siswa, Model pembelajaran Reciprocal Teaching

\begin{abstract}
This research is a quasi-experimental research by obtaining relevant information for the problems studied and using objective analysis to obtain valid conclusions. For data collection tools, tests and observations are used. From the results of the pre-test, 34 students have not succeeded in understanding the set material. Meanwhile, 6 students have managed to understand the set material. Judging from the average initial ability of students before the set material was taught, it was 47.38. So the level of student mastery on the set material with conventional learning is very low. After learning with Reciprocal Teaching, it was found that 2 students had not succeeded in understanding the subject of the volume of cubes and blocks. Meanwhile, 38 students have succeeded in understanding the set material. Judging from the average initial ability of students before the application of the Reciprocal Teaching learning model on the set material, that is 47.38 and after making improvements to the learning outcomes, the data obtained is 80.13 , then the comparison of students' mastery levels on the set material can be improved, namely the category is good. Based on the results of the study, it can be concluded that there is an increase in students' creative thinking skills who are taught after applying the Reciprocal Teaching learning model to the set material in class VII MTsS Utama Nagasaribu for the 2020-2021 academic year.
\end{abstract}

Keywords: students' creative thinking ability, Reciprocal Teaching learning model

\section{PENDAHULUAN}

Pembelajaran matematika perlu diberikan kepada siswa sejak dari sekolah dasar sampai keperguruan tinggi. Sehubungan dengan itu pemerintah terus berusaha untuk meningkatkan mutu pengajaran matematika sesuai dengan pendapat Hudojo (1988 : 74) "Matematika bukanlah ilmu yang hanya untuk keperluan dirinya sendiri, tetapi ilmu yang bermanfaat untuk sebagian amat besar ilmu-ilmu lain. Dengan perkataan lain, matematika mempunyai peranan yang sangat esensial untuk ilmu lain, yang utama sains dan teknologi”. Hal ini merupakan salah satu penyebab hasil belajar matematika siswa tidak sesuai dengan yang diharapan.

Banyak faktor yang dapat mempengaruhi sehingga menyebabkan kemampuan siswa dalam belajar matematika rendah. Diantaranya proses pembelajaran yang dilaksanakan guru masih bertumpu pada guru dimana guru berperan aktif sedangkan siswa pasif, seorang guru mentransfer ilmu sedangkan siswa hanya menerima dan tidak ada timbal balik yang terjadi dalam proses pembelajaran. Pembelajaran ini yang sering disebut pembelajaran secara konvensional. 
ISSN. 2621-9832

JURNAL MathEdu (Mathematic Education Journal) http://journal.ipts.ac.id/index.php/MathEdu

Vol. 4. No. 3 November 2021

Salah satu cara yang dapat digunakan untuk mengatasi masalah tersebut, perlu digunakan suatu alternatif pembelajaran yang dapat meningkatkan motivasi belajar siswa sehingga tujuan pembelajaran dapat tercapai yaitu dengan pembelajaran dengan menggunakan model pembelajaran kooperatif. Pada pembelajarannya menggunakan kelompok-kelompok kecil sehingga pembelajaran akan lebih bergairah.

Banyak model pembelajaran yang merangsang siswa untuk belajar kreatif, aktif, dan mandiri. Salah satunya adalah pendekatan Reciprocal Teaching. Model pembelajaran Reciprocal Teaching adalah salah satu dari model pembelajaran kooperatif dalam matematika. Reciprocal Teaching atau pembelajaran terbalik awalnya dirancang untuk mengatasi kesulitan belajar dalam membaca teks.

\section{METODE PENELITIAN}

Penelitian ini akan dilaksanakan di MTsS Utama Nagasaribu karena tempat penelitian berada dilingkungan tempat tinggal peneliti sehingga akan memudahkan peneliti untuk mendapatkan informasi dan data yang akurat dalam pelaksanaan penelitian. Waktu penelitian

Dalam penelitian ini penulis menggunakan tes sebagai alat pengumpul data. Tes merupakan instrumen pengumpulan data karena tes adalah serangkaian pertanyaan atau latihan yang digunakan untuk mengukur keterampilan, pengetahuan, inteligensi, kemampuan, atau bakat yang dimiliki oleh individu atau kelompok. Tes yang digunakan berbentuk essay test yang terdiri dari materi himpunan. Tes terdiri dari jenis yaitu tes awal dan tes akhir.

Peneliti melaksanakan penelitian ini dengan penelitian eksperimen semu. Jenis penelitian ini adalah quasi eksperimen (eksperimen semu) yaitu penelitian yang mendekati penelitian true experimen dimana tidak mungkin mengadakan kontrol atau memanipulasi semua variabel yang relevan. Desain penelitian yang digunakan adalah Pretest-Posttest Control Group Design yakni eksperimen yang dilaksanakan pada dua kelompok dimana salah satunya sebagai kelompok pembanding. Penelitian ini melibatkan dua kelas yaitu kelas eksperimen dan kelas kontrol

Pada penelitian ini desain yang digunakan adalah One Group Pre-Test Post Test. Design yang merupakan eksperimen yang dilaksanakan pada 1 kelompok saja tanpa kelompok pembanding. Desain ini digambarkan sebagai berikut:

\begin{tabular}{cccc}
\hline Kelas & Pretest & Perlakuan & Postest \\
\hline Eksperimen & $\mathrm{Y}_{1}$ & $\mathrm{X}_{1}$ & $\mathrm{Y}_{2}$ \\
\hline Kontrol & $\mathrm{Y}_{1}$ & $\mathrm{X}_{2}$ & $\mathrm{Y}_{2}$ \\
\hline
\end{tabular}

Keterangan :

Tabel 1 Desain Penelitian Pretest-Posttest Control Group Design

$\mathrm{Y}_{1} \quad$ : Tes awal (pre test) yang diberikan pada kelas kontrol dan eksperimen.

$\mathrm{X}_{1} \quad$ : Perlakuan pada kelas eksperimen yaitu model pembelajaran Reciprocal Teaching pada materi himpunan.

$\mathrm{X}_{2} \quad$ : Perlakuan pada kelas kontrol yaitu pembelajaran konvensional.

$\mathrm{Y}_{2} \quad$ : Tes akhir (post test) yang diberikan pada kelas eksperimen dan kelas kontrol

Populasi penelitian adalah wilayah generalisasi yang terdiri atas objek/subjek yang mempunyai kwantitas dan krakteristik tertentu oleh peneliti untuk dipelajari dan kemudian ditarik kesimpulan. Adapun populasi yang akan ditetapkan oleh peneliti sebagai populasi penelitian adalah seluruh siswa kelas VII MTsS Utama Nagasaribu.

Sampel dari penelitian ini adalah seluruh siswa kelas VII-B yang berjumlah 32 siswa untuk kelas eksperimen dan kelas VII-A yang berjumlah 32 siswa untuk kelas kontrol siswa. MTsS Utama Nagasaribu yang hanya terdiri dari dua kelas untuk kelas VII dengan demikian penelti menggunakan semua siswa yang ada untu menjadi sampel pada penelitian.

Hipotesis yang akan di uji dirumuskan sebagai berikut :

$\mathrm{H}_{0}: \mu_{1} \leq \mu_{2}$

Dimana :

$\mathrm{H}_{\mathrm{a}}: \mu_{1}>\mu_{2}$

$\mathrm{H}_{0} \quad$ : Kemampuan berpikir kreatif siswa yang diajarkan dengan menggunakan Reciprocal Teaching lebih rendah atau sama dengan kemampuan kemampuan berpikir kreatif siswa yang diajarkan dengan menggunakan model pembelajaran konvensional pada materi himpunan di kelas VII MTsS Utama Nagasaribu.

$\mathrm{H}_{\mathrm{a}} \quad$ : Kemampuan berpikir kreatif siswa yang diajarkan dengan menggunakan model pembelajaran Reciprocal Teaching lebih tinggi atau lebih baik dibandingkan dengan kemampuan berpikir kreatif 
ISSN. 2621-9832

JURNAL MathEdu (Mathematic Education Journal) http://journal.ipts.ac.id/index.php/MathEdu

Vol. 4. No. 3 November 2021

siswa yang diajarkan dengan menggunakan model pembelajaran konvensional pada materi himpunan MTsS Utama Nagasaribu.

$\mu_{1} \quad$ : Rata-rata kemampuan berpikir kreatif kelas eksperimen (pengajaran dengan model pembelajaran Reciprocal Teaching).

$\mu_{2} \quad$ : Rata-rata kemampuan berpikir kreatif kontrol (pengajaran dengan model pembelajaran konvensional).

Alternatif Pemilihan Uji t

1. Jika data berasal dari populasi yang homogen $\left(\sigma_{1}=\sigma_{2}\right.$ dan $\sigma$ tidak diketahui), maka digunakan rumus uji t yaitu :

$$
t=\frac{\overline{X_{1}}-\overline{X_{2}}}{S \sqrt{\frac{1}{n_{1}}+\frac{1}{n_{2}}}}
$$

(Sudjana, 2005:239)

Dengan

$$
S^{2}=\frac{\left(n_{1}-1\right) S_{1}^{2}+\left(n_{2}-1\right) S_{2}^{2}}{n_{1}+n_{2}-2}
$$

2. Jika data berasal dari populasi yang tidak homogen $\left(\sigma_{1} \neq \sigma_{2}\right.$ dan $\sigma$ tidak diketahui), maka digunakan rumus uji t yaitu :

$$
t=\frac{\overline{X_{1}}-\overline{X_{2}}}{\sqrt{\frac{s_{1}^{2}}{n_{1}}+\frac{s_{2}^{2}}{n_{2}}}} \quad \text { (Sudjana, 2005:241) }
$$

Keterangan :

$\mathrm{t}=$ luas daerah yang dicapai

$n_{1} \quad=$ banyak siswa pada sampel kelas eksperimen

$n_{2} \quad=$ banyak siswa pada sampel kelas kontrol

$S_{1} \quad=$ simpangan baku kelas eksperimen

$S_{2} \quad=$ simpangan baku kelas kontrol

$S^{2} \quad=$ simpangan baku gabungan dari $S_{l}$ dan $S 2$

$\overline{X_{1}} \quad=$ rata-rata selisih skor siswa kelas eksperimen

$\overline{X_{2}} \quad=$ rata-rata selisih skor siswa kelas kontrol

Kriteria pengujian adalah : terima $\mathrm{H}_{0}$ jika $t_{\text {hitung }}<t_{\text {tabel }}$ dan tolak $\mathrm{H}_{0}$ jika $t_{\text {hitung }} \geq t_{\text {tabel }}$ dengan $\mathrm{dk}=\left(n_{1}+n_{2}-2\right)$ dengan peluang $(1-\alpha)$ dan taraf nyata $\quad \alpha=0,05$.

\section{HASIL PENELITIAN DAN PEMBAHASAN}

Dalam penelitian yang menggunakan dua model pembelajaran yang berbeda yaitu pembelajaran Reciprocal Teaching dan pembelajaran Konvensional akan dilihat kemampuan berpikir kreatif siswa pada kelas eksperimen dan kelas kontrol. Data kemampuan berpikir kreatif siswa di peroleh dengan memberikan tes uraian sebanyak 8 soal pada pretest dan posttest.

Sebelum dilakukan penelitian terlebih dahulu dilakukan pretest yang bertujuan untuk mengetahui kemampuan awal siswa tanpa dipengaruhi pembelajaran dan menjadi dasar dalam pengelompokkan siswa. Dari hasil pemberian pretest di peroleh nilai rata-rata pretest siswa kelas eksperimen adalah 50,031 sedangkan nilai rata-rata pretest siswa kelas kontrol adalah 46,750. Data selengkapnya dapat di lihat pada lampiran. Secara ringkas hasil pretest kedua kelompok dapat dilihat pada tabel berikut :

Tabel 2

Data Pretest Kelas Eksperimen dan Kelas Kontrol

\begin{tabular}{cccc}
\hline No. & Statistik & Kelas Eksperimen & Kelas Kontrol \\
\hline 1. & $\mathrm{~N}$ & 32 & 32 \\
\hline 2. & Jumlah Nilai & 1601 & 1496 \\
\hline 3. & Rata-rata & 50,031 & 46,750 \\
\hline 4. & S. Baku & 18,322 & 19,629 \\
\hline 5. & Varians & 335,709 & 385,290 \\
\hline 6. & Maksimum & 84 & 82 \\
\hline 7. & Minimum & 20 & 20 \\
\hline
\end{tabular}

Catatan : Skor maksimum tes kemampuan berpikir kreatif adalah 100 
ISSN. 2621-9832

JURNAL MathEdu (Mathematic Education Journal) http://journal.ipts.ac.id/index.php/MathEdu Vol. 4. No. 3 November 2021

Setelah kemampuan berpikir kreatif diketahui, dibentuklah kelompok pada kelas eksperimen. Untuk kelas eksperimen yaitu kelas VII-B diterapkan pembelajaran dengan menggunakan model pembelajaran Reciprocal Teaching yang terdiri dari 4 kelompok besar yang beranggotakan 8 orang, kemudian untuk setiap kelompok besar dibagi menjadi kelompok kecil yang beranggotakan 2 orang. Sedangkan pada kelas kontrol yaitu kelas VII-A diterapkan pembelajaran dengan menggunakan model pembelajaran Konvensional. Pada akhir pertemuan, masing-masing siswa diberikan posttest. Tujuan diberikan posttest adalah untuk mengetahui kemampuan berpikir kreatif kedua kelas setelah dilakukan pembelajaran dengan menggunakan model Reciprocal Teaching pada kelas eksperimen dan model Konvensional pada kelas kontrol. Data selengkapnya dapat di lihat pada lampira. Secara ringkas hasil posttest kedua kelompok dapat dilihat pada tabel 4.2. berikut

Tabel 3

Data Posttest Kelas Eksperimen dan Kelas Kontrol

\begin{tabular}{cccc}
\hline No. & Statistik & Kelas Eksperimen & Kelas Kontrol \\
\hline 1. & $\mathrm{~N}$ & 32 & 32 \\
\hline 2. & Jumlah Nilai & 2246 & 2042 \\
\hline 3. & Rata-rata & 70,188 & 63,813 \\
\hline 4. & S.Baku & 13,895 & 15,403 \\
\hline 5. & Varians & 193,060 & 237,254 \\
\hline 6. & Maksimum & 92 & 86 \\
\hline 7. & Minimum & 37 & 36 \\
\hline
\end{tabular}

Catatan : skor maksimum tes kemampuan berpikir kreatif adalah 100

Dari hasil perhitungan pretest dan posttest di atas dapat dilihat perbedaan rata-rata pretest dan posttest kelas eksperimen dan kelas kontrol. Secara ringkas nilai rata-rata siswa kedua kelas baik pretest dan posttest dapat dilihat pada tabel 4.3 dan dalam bentuk diagram pada gambar 4.1.

Tabel 4

Ringkasan Rata-rata Nilai Pretest dan Posttest Kedua Kelas

\begin{tabular}{ccccc}
\hline \multirow{2}{*}{ Keterangan } & \multicolumn{2}{c}{ Kelas Eksperimen } & \multicolumn{2}{c}{ Kelas Kontrol } \\
\cline { 2 - 5 } & Pretest & Posttest & Pretest & Posttest \\
\hline Jumlah Nilai & 1601 & 2246 & 1496 & 2042 \\
\hline Rata-rata & 50,031 & 70,188 & 46,750 & 63,813 \\
\hline
\end{tabular}

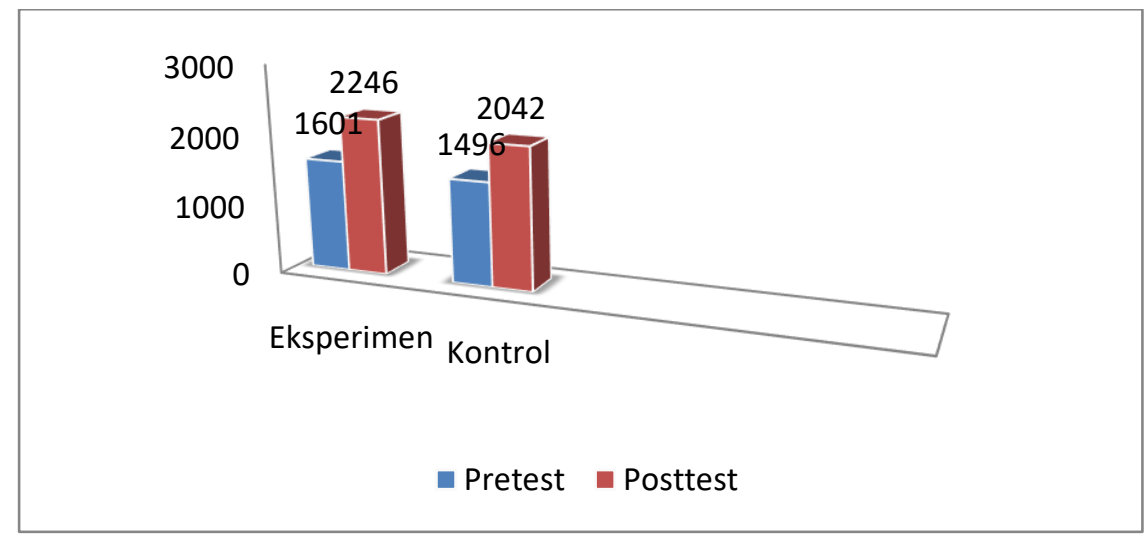

Gambar 1 Gambar Rata-Rata Nilai Pretest dan Posttest Kedua Kelas

Secara deskriptif ada beberapa kesimpulan yang berkenaan dengan kemampuan berpikir kreatif yang dapat diungkap dari Tabel 4.3 dan gambar 4.1. di atas, yaitu :

a. Rata-rata pretest kemampuan berpikir kreatif kelas eksperimen $(50,031)$ lebih tinggi dibandingkan dengan rata-rata pretest kelas kontrol $(46,750)$ atau pretest eksperimen lebih besar dari pretest kontrol.

b. Rata-rata posttest kemampuan berpikir kreatif kelas eksperimen $(70,188)$ lebih tinggi dibandingkan dengan rata-rata posttest kelas kontrol $(63,813)$ atau posttest eksperimen lebih besar dari posttest kontrol. 
ISSN. 2621-9832

JURNAL MathEdu (Mathematic Education Journal) http://journal.ipts.ac.id/index.php/MathEdu

Vol. 4. No. 3 November 2021

c. Selisih rata-rata pretest antara kelas eksperimen dan kelas kontrol sebesar 3,281 dan selisih rata-rata posttest kelas eksperimen dan kelas kontrol sebesar 6,375

Mencermati hasil penelitian yang telah dikemukakan pada sub bab sebelumnya, di peroleh bahwa model pembelajaran Reciprocal Teaching (kelas eksperimen) lebih baik dalam meningkatkan kemampuan berpikir kreatif siswa dibandingkan dengan model pembelajaran Konvensional (kelas kontrol). Sebelum penelitian dilaksanakan terlebih dahulu diberikan pretest yang bertujuan untuk mengetahui kemampuan awal siswa dan berguna untuk pembentukan kelompok pada kelas eksperimen. Setelah data siswa pretest diketahui, dibentuklah kelompok heterogen pada kelas eksperimen dengan empat kelompok besar dan kemudian dibagi menjadi kelompok kecil yang beranggotakan dua orang.

Pada kelas eksperimen dilakukan pembelajaran Reciprocal Teaching dengan memperkenalkan subtopik yang akan dipelajari. Kemudian masing-masing siswa diberikan LAS (Lembar Aktifitas Siswa) untuk mendiskusikan soal yang diberikan guru. Setelah waktu diskusi yang diberikan habis, maka siswa akan bertukar pasangan sehingga masing-masing siswa akan memperoleh pasangan baru dan berbagi informasi yang berbeda. Dengan cara diskusi diharapkan siswa dapat berkomunikasi, menyampaikan ide yang mereka peroleh dan saling berbagi informasi untuk soal yang mereka kerjakan. Hasil diskusi pada kelompok besar kemudian dipresentasikan dan guru memberikan kesempatan kepada kelompok besar lainnya untuk memberikan pendapat. Kemudian guru bersama siswa meyimpulkan jawaban dari masalah yang diajukan.

Dari hasil penelitian diperoleh bahwa rata-rata kemampuan berpikir kreatif siswa yang diajarkan dengan menggunakan model pembelajaran Reciprocal Teaching lebih baik dari rata-rata kemampuan berpikir kreatif siswa yang diajarkan dengan model pembelajaran Konvensional. $\mathrm{H}_{0}$ ditolak dan $\mathrm{H}_{\mathrm{a}}$ diterima yang artinya bahwa kemampuan berpikir kreatif siswa yang diajarkan dengan menggunakan model pembelajaran Reciprocal Teaching lebih tinggi atau lebih baik daripada kemampuan berpikir kreatif siswa yang diajarkan dengan menggunakan model pembelajaran Konvensional pada materi himpunan di kelas VII MTsS Utama Nagasaribu Rata-rata pretest kemampuan berpikir kreatif kelas eksperimen $(50,031)$ lebih tinggi dibandingkan dengan rata-rata pretest kelas kontrol $(46,750)$ atau pretest eksperimen lebih besar dari pretest kontrol. Ratarata posttest kemampuan berpikir kreatif kelas eksperimen $(70,188)$ lebih tinggi dibandingkan dengan ratarata posttest kelas kontrol $(63,813)$ atau posttest eksperimen lebih besar dari posttest kontrol.

\section{KESIMPULAN DAN SARAN}

Berdasarkan hasil penelitian dan pemahaman diperoleh beberapa kesimpulan yaitu: Secara statistik dengan menggunakan uji-t disimpulkan bahwa kemampuan berpikir kreatif siswa yang diajarkan dengan menggunakan model pembelajaran Reciprocal Teaching lebih baik daripada kemampuan berpikir kreatif siswa yang diajarkan dengan menggunakan model pembelajaran konvensional pada materi himpunan kelas VII MTsS Utama Nagasaribu Tahun Pelajaran 2020-2021. Hal ini dapat dilihat dari hasil pengujian hipotesis dimana $t_{\text {hitung }}(1,738)>t_{\text {tabel }}(1,67)$.

\section{REFERENSI}

Andiyana, M. A., Maya, R., \& Hidayat, W. 2018. Analisis Kemampuan Berpikir Kreatif Matematis Siswa SMP Pada Materi Bangun Ruang. JPMI (Jurnal Pembelajaran Matematika Inovatif), (Daring), Vol.1(3): 239 248 . Tersedia: https://journal.ikipsiliwangi.ac.id (27 Agustus 2019).

Arifiyandy, Risky Gani. 2014.Peningkatan Hasil Belajar Matematika melaluiModel Riceprocal Teaching Materi Segi Empat Siswa Kelas IIISemester I SMP Negeri 2 Porong, SKRIPSI, (Online), http:lpmpsumut.or.id/wp-content/2014. Diakses pada tanggal7 Oktober

Bahri Syaiful, Djamarah dkk.( 1995) Strategi Belajar Mengajar. Jakarta: Rhineka Cipta,

Birgili, Bengi (2015:72). Creative and Critical ThinkingSkills in Problem-based Learning Environments. Journal of Gifted Education and Creativity, 2(2), 71-80. https://scholar.google.co.id/scholar?q=Creative+and+Critical+ Thinking+Skills+in+Problembased+Learning+Environments\&btnG $=\&$ hl =id\&as sdt=0\%2C5\&as vis=1. diakses 21 Januari 2017).

Departemen Pendidikan dan Kebudayaan, (2004), Kurikulum Sekolah Menengah Pertama, Jakarta: Depdikbud, hal. 216

Hudojo, H, (1988), Mengajar Belajar Matematika, Depdikbud, Jakarta.

Johnson, Elaine B (2006), Contextual Teaching \& Learning, Memjadikan Kegiatan Belajar-Mengajar Mengasyikkan Dan Bermakna. MLC, Bandung.

Moma, La (2012 : 508). Menumbuhkan Kemampuan Berpikir Kreatif Matematis Melalui Pembelajaran Generatif Siswa SMP. PROSIDING. ISBN : 978-979-16353-8-7. (http://eprints.uny.ac.id/8102/1/P\%20-\%2053.pdf. Di akses 12 Oktober 2016)

Noer, S. H. 2009. Kemampuan Berpikir Kreatif Matematis Apa, Mengapa, dan Bagaimana? (pp. 521 \pm 526 ). 
JURNAL MathEdu (Mathematic Education Journal) http://journal.ipts.ac.id/index.php/MathEdu Vol. 4. No. 3 November 2021

In Lampung: Prosiding Seminar Nasional Penelitian, Pendidikan dan Penerapan MIPA Fakultas MIPA, Universitas Negeri Yogyakarta (Vol. 16).

Palincsar,A.S\&Brown,A.,(1986),http://www.ncrel.org/sdrs/areas/issues/students/atrisk/at6lk38.html (Diakses 2 Februari 2012).

Siswono (2005) Upaya Meningkatkan Kemampuan Berpikir Kreatif Siswa Melalui Pengajuan Masalah. Jurnalterakreditasi “JurnalPendidikanMatematikadanSains", FMIPA UniversitasNegeri Yogyakarta.

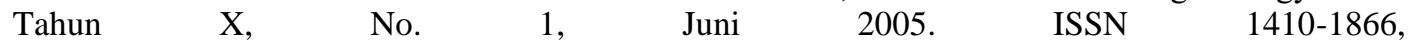
(https://tatagyes.files.wordpress.com/2009/11/paper05_problemposing.pdf diakses 13 Oktober 2016)

Sudjana, Nana. 2001. Penilaian Hasil Proses Belajar Mengajar. Remaja Rosdakarya. Bandung

Trianto. (2009). Mendesain Model Pembelajaran Inovatif-Progresif. Surabaya: Kencana

Trianto, (2010), Model-Model Pembelajaran Inovatif Berorientasi Kontruktivistik, Penerbit Prestasi Pustaka, Jakarta.Prenada Media Grup

Zainuddin, M. 1999. Metodologi Penelitian. Surabaya: UNAIR 